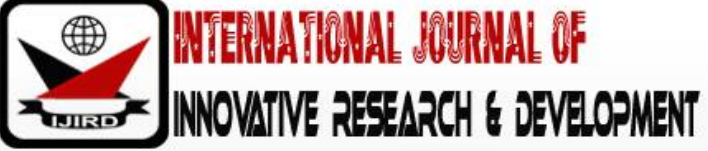

ISSN 2278 - 0211 (Online)

\section{A Karu Based Experience about the Effect of Informal Land Delivery Channels' on Housing Supply}

Daniel Adamu
Lecturer, Department of Urban and Regional Planning,
Nasarawa State University Keffi, Nigeria
Austine Audu Danladi
Area Town Planning Officer, Department of Development Control,
Nasarawa State Urban Development Board, Nigeria

\begin{abstract}
:
For a long period of time, urban land delivery system in Nigeria has seen a stable association between formal and informal channels, which is going till date. Instead of the provision of the Land Use Act of 1978, which granted states (the second tier of government in Nigeria) the authority to hold and administer all lands within their territorial jurisdiction, interests for urban land are still largely being expressed through the informal mechanisms. These transactions continue defying all odds associated to it. This research established the extent to which informal land delivery channels has influenced housing supply in Karu, the gateway city to Nigeria's capital Abuja. Data were obtained through primary sources, analyzed, and presented in matrixes. The outcome of this research suggests about the accessibility and economical value of lands. This has led development and financing options are the important factors that influence the choices of urban residents particularly the majority who are the low-medium income earners preferences of informal land delivery for their housing development. Despite their deficiencies as it regards; tenure security has been strengthened by its social legitimacy and possible upgrade to statutory status.Thus, the main conclusion of the study is that the predominant influence of these factors on the urban land market will continue to sustain the informality of land access and directly determine the rate of residential housing supply in most Nigerian cities. The study recommends that the operations of the informal land channel should be standardized as it promises to bea sustainable alternative to the formal system.
\end{abstract}

Keywords: Informal land delivery, housing supply, Karu

\section{Introduction}

Land is universally known from time immemorial to be very crucial to the success of not only housing, but other developmental needs of man such as roads, hospital, and schools etc which are necessity to improving human's living standards. However, as human population and the need for shelter increases, so also the demand for land to meet up the need which also has resulted in making access to land bureaucratically complex through the public institution. Hence informal initiatives have been thoughtfully evolved by man to accelerate access to land for human development. This initiative becomes necessary to compliment the weaknesses of the formal system which is responsible for supplying land for development, but unable to successfully do that, (Rakodi, 2005).

Therefore, as it is with most cities in developing countries, the rapid growth of Karu has put much pressure on land that demand has far outweighed supply through the formal channel (Adamu 2014).Almost every residential in Karu has been provided with informal land delivery process in recent time frame. It is appositive side that informal channel has been designed for both urban land rights holders as well as urban and rural people residing over there and seek for housing (Rakodi and Leduka 2003). This delivery process had been highlighted in the work of Rakodi. All common formalities under social rules for formal land regulation have been accepted and well understood by both actors and systems. As per Rakodi (2005), success of informal land delivery systems can be evaluated by the percentage of people getting land. It depends on many practical parameters as well as laws. This is a major reason why informal land delivery systems vary from time to time. The author also discussed that there is some sort of negligence from government side occurs due to coerce generated by land markets of urban. This article sought to bring insights on influence of informal land delivery on housing supply. The empirical evidence from Karu the gate way into the nation's capital city of Abuja from the eastern part aimed specifically at describing the effects of informal land delivery on housing supply perspectives, the associated influences on the quantum of housing stock delivered in the city.

\subsection{Land Delivery and Land Tenure Systems in Nigeria}

Before pre-colonial era, mainly communities were responsible for land transactions. Various racial groups were handling this based on heritage and rituals. According to Adeniyi (2013), based on social, cultural, economic situations 
owners of community and head of families were responsible to maintain land related transactions. Power and authority, mainly obtained through heritage, were the main factor behind setting a head or key person for this purpose. As per Lamond, Awuah, Lewis, Bloch and Falade (2015), mostly male, few females were allowed to carry this duty. Lamondet al. (2015), highlighted that foisting of British on land authority gave birth to formal urban planning as well as segregation among locations. Adeniyi (2013), mentioned that, until 1978, colonial land policies co-existed with traditional one after independence in 1960. After independence for urban planning two major laws had been passed in Nigeria. Both of these based on Land Use Decree of 1978 focusing mainly on land and its management, and the Urban and Regional Planning Decree of 1992. The last one got revised in 1999. According to Lamond et al. (2015), both of these had highlighted on developmental aspects related to technical, legal and administrartive. Based on current urban land administration, planning and governance arrangement, both formal and informal land delivery systems have transpired.

\subsubsection{Formal Land Delivery}

Based on formal land administration, planning and governance processes, formal land delivery system had come into view. The primary legal framework behind this is the Land Use Act of 1978. According to Ikejiofor, Nwogu, and Nwanunobi (2004), state governor directed that the conversion of old estate into rights of occupancy meaning that the existing right of occupancy ( $\mathrm{R}$ of $\mathrm{O}$ ) has to be covered by a Certificate of Occupancy ( $\mathrm{C}$ of $\mathrm{O}$ ). Many quasi-state institutions such as local governments have been created under the Urban and Regional Planning Decree (1992). For planning, survey, maintenance of infrastructure of lands these bodies are being responsible. According to Lamond et al. (2015), under formal development process many actviies by public institutions as well as allocation of land and/ or grant of ' $\mathrm{C}$ of $\mathrm{O}$ ' over customary lands are being covered.

\subsubsection{Informal Land Delivery}

Informal land delivery is a term that is used to describe the process of making land available through informal process that encompasses inheritance, informal purchase, squatting, private donation, etc (UN HABITAT, 2010). Transfer of land ownership is done orally with an unofficial sale contract signed by the land seller, the buyer and a few witnesses from either side or proof of inheritance, and not officially recorded. Thirkell (1996) noted that information on land to be sold was spread through social network or through informal advertisement.

According to Thirkell "Informal" land in this context refers to land for which the occupier has no legal documentation of ownership such as a title or any approval from the legal owner to occupy the land (Thirkell, 1996). Another interesting perspective is the size of land to be sold and land price in informal channels are negotiated often discreetly until the final agreement is reached, when disclosure to witnesses to the sale agreement is made and payment of money completed. Intending land users utilize this process because it eliminates time wastage and reduces transaction costs (Nkurunziza, 2008). Notwithstanding, Thirkell aired out inconsistencies in determining the price of land in informal land market (Thirkell, 1996). It was also found that land informally acquired most of the time has no legal title or no statutory approval (Kironde,2000).

In the context of Nigeria, land can be statutorily-owned, or privately-owned. Land privately-owned is usually acquired through inheritance, donation, formal or informal purchase, and squatting on public land. In Nigeria urban centres, as observed by many scholars (Rakodi C. 2003), private-owned land is mainly acquired through informal land market.

\subsection{Housing Delivery in the Context of Land Accessibility}

The term housing delivery could depict several meanings based on a particular perspective. It is a step that involves transforming or increasing the application of land to construct shelters for habitation. Land is just a unit of several other factors of housing production which may include labour, finance and professional services (Oduwaye, 1998). In other words, housing delivery may be analysed as a process that involves comprehensive steps that are sequentially followed to produce a housing unit or units. This process fundamentally requires the gathering of housing materials such as, finance, labour, building materials and land to produce new housing. Housing delivery system also involves the strategy, procedure and methods of producing the existing stock needed by the household. Thus, the housing supply entails the entire arrays of actions necessary in the construction and allocation of housing to households (Makinde, 2014). Increasing cost of land has been one of the greatest problems to housing delivery and affordability in Nigeria, especially in urban areas (Oloyede 2011). Cost of land characteristically pushes up construction costs and makes housing too expensive for the reach of majority of the urban households in most of the developing nations. Various studies have demonstrated that there is generally a shortage of housing stock to meet the current urban demand especially from the mid and low income classes a result of difficulties imposed by the legislative framework around procurement of land via formal access to land (Isma'il et al., 2015). Household income, ability to save, access to credit and the number of people who want to hold land as an investment are the factors that affect demand for urban land. However, topography, government zoning regulations on land, the spatial pattern of infrastructure, and the willingness of landowners to make land available on the market, are also the factors that affect supply of land. The land market is complex with several players and may have differing interest (Thellane, 2008). Urban land markets are being influenced by law of demand and supply; the economic forces of supply and demand are dominant features of land markets. These features inform the availability of land for affordable housing which they either promote exclusion, or hinder the inclusion of the poor into urban land markets (Thellane, 2008). It has been pointed out that land sale markets fail to transfer enough land to meet the needs of poor households that have the desire and ability to buy land (Hanstad et al., 2004). 
Many social analysts provided ways for improving housing productions in Nigeria including Oduwaye (1998) who advocated for a simple land allocation system. The price of land is not at the reach of many people and even where public sector partners with private sectors developers, the land allocation costs and charges make it impossible to deliver the housing units at an affordable price for the low-income market, (Makinde, 2014). Location of the property is also influence house prices in Nigeria; both sales and rental prices are higher in urban areas than rural areas. Hence most low-income housing is located in suburbs of major cities. However, as the cities expand; these suburbs soon become part of the cities, (Makinde, 2014)

In Nigeria, many significant attempts have been made including the promulgation of the Land Use Act of 1978 to step up land available for affordable housing (Owoeye and Adedeji, 2015); this Act focused to push 'surplus' urban land onto the market by limiting the part of land that could be owned by private landowners and any excess land could be acquired by the state very cheaply and used to build low income housing. However, implementation of the Land Use Act of 1978 in Nigeria has failed to reach this noble goal. Hence, pushing land prices even higher (Wadhwa, 1988; Lamond et al., 2015). It has been argued that the failure of formal access to land arrangements in the country to meet the demands of the majority of urban residents for developable lands and services especially in the face of rapid urbanization has given rise to alternative (informal) forms of land delivery and development (Lamondet al., 2015; Adam, 2014).

\subsection{Challenges Militating Against Sustainable Land and Housing Markets in Nigeria}

Majority of policies related with land and housing which had seen success in other parts of countries had been applied in Nigeria also. "Federal Housing Authority" and "State Housing Corporations" are some of the examples. Like other developed and developing countries, some examples of policies are low, medium and high-income housing schemes by both the federal and state governments; provision of site and services schemes across the states; National Housing Fund Scheme; the Federal Mortgage Bank of Nigeria as an apex mortgage institution and the Primary Mortgage Institutions. Under pre-capitalist social formation, land is the core component, felt by people of Northern or Southern Nigeria. This is why in the beginning of the $20^{\text {th }}$ century, it was not sold. But as time passed it become a matter of negative contest in the forms of litigation and communal strife. Many other practices like multiple sales of the same land to different buyers by land-owning families, land speculation are being stared practicing in Southern Nigeria. Many other facts like price hike of lands, indictments, excessive compensations, shortage of lands have been noticed. To solve these issues Land Use Decree (now Act) had been enforced from 29thMarch, 1978. The main purpose was to get easier access for land (Mabogunje, 2002). As per this Act, all lands will be used by Nigerian citizens. Bodies known as Land Use and Allocation Committee, and similarly, a Land Allocation Advisory Committee have been formed to handling various responsibilities like allocation etc. State and local governments can allow right of occupancy under Section 5 and 6 respectively. There is a limitation that maximum one half of a hectare of underdeveloped land can be acquired by anyone. Another one is that in rural the land must not cross 500 hectares and 5000 hectares respectively for agricultural and grazing purposes. For every action permission will be granted by Governor. This act has been criticized due to its limited application on rural area only. Sections 29 and 48 of the Act are mainly covers customary tenure of land. Plenty of land tenure and management systems are there. As per Kasaga and Kotey (2001), these are mostly non-functional. In Nigeria both formal and informal channels exist. Under Land Use act, 1978, formal sectors such as, state Ministry of Lands and Housing, the state and federal governments housing authorities and property corporations are operating. Stools, kins, families, agents are the most common parts of informal channel. In spite of this, still accession of land is still a problem. Mabogunje (2002), mentioned that cost, time, complex procedures like land registration, accessibility have made formal systemtough to use. Moreover, formal channels have mentioned as administrative procedures which are time taking, sedate and not simple (Harare, Mubvanic and Musandu, 1994).The main reason for slow performance for delivery has been caused by many unnecessary participants.

\subsection{Determinants of Housing Delivery}

Housing delivery in Nigeria is the responsibility of either the Government or Private sector, in spite Federal Government effort to facilitate access to land for housing development; the country could only meet 4.2 percent of the annual demand (Adekemi, 2014). It is pertinent to note that private sector developers are responsible for most of urban housing (Olugbenga, 2014). About 90\% of urban housing is developed by private individuals or organizations (Omole, 2009). Housing demands originated from rural- urban migration accounts for about 65 percent of urban population growth, the fixed delivery of urban land, and inflation of rental and housing ownership cost has increase in the past decade. However, according to Sulyman, an effective housing supply programme will require some unavoidable determinants factors such as availability and cost of land, availability and cost of building materials, availability and cost of skilled labour, availability of infrastructure and services, availability and access to mortgage (financial housing), efficiency of government policy and strategies on housing, quantity and quality of existing stock, to influence its success (Sulyman 2015). Meanwhile, in respect to this paper only the availability and cost of land has direct relevance to what the paper sets to achieve, hence it will be briefly discussed for better understanding.

\subsection{Availability and Cost of Land}

Housing supply requires land as a basic determinant for its success. Therefore, availability of buildable land in terms of ease of access and cost of securing plots influence housing supply (Sulyman, 2015). Land is one of the most important resources in the construction industry. It is a sine-qua-non for housing development, as the house building process remains only a mirage without the availability of land. The available developable land has consistently been in decline globally due to the implementation of various social, industrial, commercial and institutional development 
schemes. Since land is limited in supply, the possibility exists, therefore, that, someday, undeveloped land may become exhausted. This stark reality necessitates careful planning of urban land and the development of appropriate land policy, accessibility to land is highly essential for effective housing delivery in any society (Ifesanya, 2012).

Housing development is particularly dependent on the availability of land, considering the fact that more than 50 percent of total land use in most cities of the world is utilized for housing. Adequate legal and administrative framework is also required to facilitate access to land for the purpose of housing development (Ifesanya, 2012). However, due to failures of the formal land as a result of its rigid conditions of operations in respect to payment and accessibility, most urban dwellers in Nigeria have to rely on their own initiative in order to find shelter through the informal land delivery where prospective buyers have the privilege of incremental strategies of payment and subsequently, embark on development. Informal land's strategy of incremental development and improvement of housing and infrastructure has succeeded in many parts of the developing countries where most of the low income earners have taken to this approach in meeting up their housing need, (Oloyede, S. A. et’al2011).

\section{Materials/ Methodology}

It is mostly a tasking venture in collecting data for research especially in most of our traditional Nigeria cities. The scenario is much more pronounced when embarking on study with little or no record base like informal land channel. Hence, to achieve our objectives, primary data were relied upon largely and a few document reviewed from previous research by the authors. From five districts Data for this study have been collected from five of the Karu urban districts such as New Karu, Mararaba, Masaka, New Nyanya, and Ado. Purposive sampling Technique has been used here. All householders, as a population are eligible for this study. A sample size of 0.25 percent has been set to carry this study. From five districts an approximated value of 310 respondents has been used for the study. The sample size was arrived at using Taro Yemane formula. According to Yamene, the sample size of 0.1-.05 is recommended for carrying out research depending on the size of your sample frame. Hence, having a sample frame of 124,043 the sample size of 0.25 that falls within the recommended sample size was adopted. These 310 respondents were spread across the five districts of Karu Urban Area. The questions related to informal land process were drawn and administered in order to ascertain the influence of the Informal Land access on housing delivery on each stratum, by large the entire city. This is summarized in the table below:

\begin{tabular}{|c|c|c|c|}
\hline Districts & $\begin{array}{c}\text { Projected } \\
\text { Population }\end{array}$ & $\begin{array}{c}\text { Household } \\
\text { Population }\end{array}$ & $\begin{array}{c}\text { Sample Size (\%) ) } \\
\text { (No of Respondents - Household Owners) }\end{array}$ \\
\hline Mararaba & 195,994 & 32,666 & 82 \\
\hline Kuruduma & 142,306 & 23,718 & 59 \\
\hline New Karu & 166,573 & 27,762 & 69 \\
\hline Ado & 70,050 & 11,675 & 29 \\
\hline Masaka & 169,333 & 28,222 & 71 \\
\hline Total & 744,256 & 124,043 & 310 \\
\hline
\end{tabular}

Table 1: Sample Distribution for Household Owners

Source: Authors Field work, 2016

\section{Results and Discussion}

\subsection{Influence of informal Access to Land for Housing Delivery}

The results of our findings in this section is strictly based on the survey conducted during the course of our research work on informal access to land for housing delivery in Karu Area of Nasarawa State. Hence, all the statistical analysis quoted in this section reflects the existing scenario in Karu as referenced by us. It is on this note that this section describes in detail the significant contribution of informal access to land and housing delivery in Karu.

\subsection{Availability of land for Housing}

As an important parameter of the type of land market, the source of land acquisition is the most influential in the urban area. Hence, an informal source of land acquisition has played the highest role in influencing housing supply in Karu. Table 2 shows that 92.6 percent of the household owners purchased their lands from Community, Individuals, Family or Traditional Leaders (informal channel) while 7.4 percent of the respondents purchased their land from the government (formal channel). This implies that informal land channel is the dominant supplier of land for housing delivery in the study area and invariably suggests its major influence on housing supply. However, more to this is that "informal land serves as the best alternative source for the provision of housing to the majority of the urban dwellers". This off-course corroborate with the findings of (Rakodi, 2005; Antwi, 2002) that informal land channel has provided solution to housing crisis in most African cities where the formal channel has failed 


\begin{tabular}{|c|c|c|c|c|c|c|c|}
\hline & New Karu & New Nyanya & Masaka & Mararaba & Ado & & \\
\hline Influence & $\begin{array}{c}\text { No. } \\
\text { of Response }\end{array}$ & $\begin{array}{c}\text { No. } \\
\text { of Response }\end{array}$ & $\begin{array}{c}\text { No. } \\
\text { of Response }\end{array}$ & $\begin{array}{c}\text { No. } \\
\text { of Response }\end{array}$ & $\begin{array}{c}\text { No. } \\
\text { of Response }\end{array}$ & Total & $\%$ \\
\hline \multicolumn{8}{|l|}{ Source } \\
\hline Formal & 10 & - & - & 13 & - & 23 & 7.4 \\
\hline Informal & 59 & 59 & 71 & 69 & 29 & 297 & 92.6 \\
\hline Total & 69 & 59 & 71 & 82 & 29 & 310 & 100 \\
\hline
\end{tabular}

Table 2: Source of Land Acquisition

Source: Author's Computation, 2016

\subsection{Affordability of Land for Housing}

The informal access in respect to housing provision has made land relatively affordable. From table 3 below, we can deduce that the prices range from as low as $\$ 100,000-2,000,000$. About 65.2 percent of the respondents spent between $\$ 500,000-1,000,000$ to acquire their land via the informal channel. This provided room for them to build their own houses in Karu with less financial constraints compared to exorbitant cost associated with formal channels. The price variations are also a factor of; location, size of land purchased, period of land acquisition, and channel of delivery among others. This revelation also buttresses several assertions made in literature that land affordability is a major factor that influence housing supply (Ifesanya, 2012).This supports the findings of (Leduka, 2006 and Rakodi, 2005), that informal land delivery provides access to land for housing development for the majority of people irrespective of their socioeconomic class.

\begin{tabular}{|c|c|c|c|c|c|c|c|}
\hline & New Karu & Kuruduma & Masaka & Mararaba & Ado & & \\
\hline Influence & $\begin{array}{c}\text { No. } \\
\text { of Response }\end{array}$ & $\begin{array}{c}\text { No. } \\
\text { of Response }\end{array}$ & $\begin{array}{c}\text { No. } \\
\text { of Response }\end{array}$ & $\begin{array}{c}\text { No. } \\
\text { of Response }\end{array}$ & $\begin{array}{c}\text { No. } \\
\text { of Response }\end{array}$ & Total & $\%$ \\
\hline $\begin{array}{c}\text { Cost } \\
\text { of Purchase }\end{array}$ & & & & & & & \\
\hline 100,000 & - & 9 & 15 & 10 & 6 & 40 & 12.9 \\
\hline $\begin{array}{c}100,000- \\
499,000\end{array}$ & 19 & 11 & 19 & 27 & 8 & 84 & 27.1 \\
\hline $\begin{array}{c}500,000- \\
999,000\end{array}$ & 29 & 29 & 22 & 31 & 7 & 118 & 38.1 \\
\hline $\begin{array}{c}1,000,000- \\
2,000,000\end{array}$ & 21 & 10 & 15 & 14 & 8 & 68 & 21.9 \\
\hline Total & 69 & 59 & 71 & 82 & 29 & 310 & 100 \\
\hline
\end{tabular}

Table 3 Affordability

Source: Author's Computation, 2016

\subsection{Encourage Incremental Housing Development}

Another interesting influence of informal land access on housing delivery is the fact that the system has provided avenue where developers can develop their houses at their own pace as their capital enables them. Table 4 provides responses from house owners in Karu Urban Area, and shows that informal land delivery encourages incremental housing development, as indicated by $86.2 \%$ who applied incremental approach in constructing their housing. This depicts the flexibility associated with informal access to land as it has the capacity to providing relatively secured access to land and enabling households to construct their dwellings incrementally (in phases) as their resources allow at a significantly lower cost and convenience, than conventional public housing programmes.

\begin{tabular}{|c|c|c|c|c|c|c|c|}
\hline & New Karu & $\begin{array}{c}\text { New } \\
\text { Nyanya }\end{array}$ & Masaka & Mararaba & Ado & & \\
\hline Influence & $\begin{array}{c}\text { No. } \\
\text { of Response }\end{array}$ & $\begin{array}{c}\text { No. } \\
\text { of Response }\end{array}$ & $\begin{array}{c}\text { No. } \\
\text { of Response }\end{array}$ & $\begin{array}{c}\text { No. } \\
\text { of Response }\end{array}$ & $\begin{array}{c}\text { No. } \\
\text { of Response }\end{array}$ & Total & $\%$ \\
\hline Development & & & & & & & \\
\hline Completed & 11 & 7 & 5 & 17 & 3 & 43 & 13.8 \\
\hline Incremental & 58 & 52 & 66 & 65 & 26 & 267 & 86.2 \\
\hline Total & 69 & 59 & 71 & 82 & 29 & 310 & 100 \\
\hline
\end{tabular}

Table 4: Encourage Incremental Housing Development

Source: Author's Computation, 2016

\subsection{Incremental Payment}

One of the triggers that attracted some developers to access land through the informal channel is its ability to allow for flexible payment mode. From table 5, we can deduce that $35.2 \%$ of the respondents attest to the fact that they made their payment in installment as against $64.8 \%$ who made one-off payment to acquire their land. This confirmed the position of Adamu who opined that informal land delivery channel allow for incremental payment. 


\begin{tabular}{|c|c|c|c|c|c|c|c|}
\hline & New Karu & $\begin{array}{c}\text { New } \\
\text { Nyanya }\end{array}$ & Masaka & Mararaba & Ado & & \\
\hline Triggers & $\begin{array}{c}\text { No. } \\
\text { of Response }\end{array}$ & $\begin{array}{c}\text { No. } \\
\text { of Response }\end{array}$ & $\begin{array}{c}\text { No. } \\
\text { of Response }\end{array}$ & $\begin{array}{c}\text { No. } \\
\text { of Response }\end{array}$ & $\begin{array}{c}\text { No. } \\
\text { of Response }\end{array}$ & Total & $\%$ \\
\hline Payment & & & & & & & \\
\hline Incremental & 15 & 26 & 34 & 21 & 8 & 140 & 35.2 \\
\hline One-off & 54 & 33 & 37 & 56 & 21 & 201 & 64.8 \\
\hline Total & 69 & 59 & 71 & 82 & 29 & 310 & 100 \\
\hline
\end{tabular}

Table 5; Incremental Payment

Source: Author's Computation, 2016

\subsection{Hypothesis Testing}

- $\mathrm{H}_{0}$ : There is no significant relationship between Informal access to Land and Housing delivery in Karu Urban Area.

- $\mathrm{H}_{1}$ : There is significant relationship between Informal access to Land and Housing delivery in Karu Urban Area.

\subsection{Chi-Square Test}

The results on Table 6 shows the observed and expected frequencies of the responses gotten for the question on the influence of informal access to land on housing delivery. This is to establish if informal land delivery has significant relationship on housing delivery in Karu Urban Area. However, it will interest us to note that 23 respondents who acquired their lands through the formal channel are not included in the Chi Square observed and expected frequencies, since our interest is on the informal land delivery. Hence, Table 7 reveals that 287 respondents were tested to see if informal access to land in Karu has influenced housing delivery.

\begin{tabular}{|c|c|c|}
\hline Response & Observed N & Expected N \\
\hline New Karu & 59 & 70.6 \\
\hline Kuruduma & 59 & 70.6 \\
\hline Masaka & 71 & 70.6 \\
\hline Mararaba & 69 & 70.6 \\
\hline Ado & 29 & 70.6 \\
\hline Total & 310 & \\
\hline
\end{tabular}

Table 6: Chi Square Frequencies

Source: Author's field survey 2016

\subsection{Test Statistics}

The outcome of the respondents' frequencies from the Likert scale were obtained and tested to ascertain the validity of this claim through the chi-square test and the results shown in Table 7. the chi square calculated value of 206.164 which is greater than the chi square critical value 9.488 at 95 percent confidence interval and a significant value $.000(\mathrm{p}<0.05)$ posits that the null hypothesis is rejected while the alternative hypothesis is accepted and therefore indicates that informal access to land in Karu Urban Area has significant relationship with housing delivery.

\begin{tabular}{|c|c|}
\hline Chi-Square $\left(\boldsymbol{\chi}^{\mathbf{2}}\right.$ calc) & $\mathbf{2 0 6 . 1 6 4}^{\mathbf{a}}$ \\
\hline$\chi^{2}$ tab & 9.488 \\
\hline $\mathrm{Df}$ & 4 \\
\hline Asymp. Sig. & .000 \\
\hline \multicolumn{2}{|c|}{ frequency is 70.6. } \\
\hline a. 0 cells (0.0\%) have expected frequencies less than 5. The minimum expected cell \\
\hline
\end{tabular}

Table 7: Test Statistics

Source: Author's Field Survey 2016

\section{Conclusion}

In Karu Urban Area majority of institutions and distribution systems for delivering land are informal. It has two disadvantages. First, many loopholes are there like low compensation paid by the government, when it comes to seize lands. This leads to aversion during accession by landlords and customary rights holders. The second point has been highlighted by Leduka (2005) about the effectiveness of informal land delivery systems. The author mentioned that the reason behind this is affable nature of its user as well as social lawfulness.

It has proper evidence from literature that informal land delivery systems in Karu, other developing countries are able to maintain its position. As a major reason for this is being mentioned that socially regularized land management, seems to be more effective compared to formal public sector. Informal land delivery has been successful for providing land to urban in a malleable and receptive manner. It is advisable that land and housing policy creation and implementation of Nigeria should match with Aribigbola (2008) highlighted socio-economic situation. All laws should be strictly followed by informal land channels. Experience from previous success should be incorporated in the Nigerian informal land and housing 
market. This is a continuous process and with globalization, Nigeria should encourage and take it as a learning process. It is very important that government should take the goal of providing easy, accessible, economic housing as their priority. Hence it can be said that informal delivery channel despite of some challenges a very effective channel for majority of urban people. It should be more standardized such that can be treated as an alternative to formal channel.Needless to say, both of these formal and informal channels can be treated as a solution for providing home to Sub-Sahara Africa's cities.

\section{Reference}

i. Adamu, D. (2014). Appraisal of the urban management challenge of informal land delivery in Karu urban area . Zaria, Nigeria: Unpublished M.Sc. URP Thesis, Ahmadu Bello University.

ii. Adeniyi, P. (2013). Improving Land Sector Governance in Nigeria. Implementation of the Land Governance Assessment Framework. A Synthesis Report. Lagos: Department of Geography, University of Lagos.

iii. Antwi, A. (2002). A Study of Informal Urban Land Transactions in Accra, Ghana. Accra, Ghana: RICS Foundation.

iv. Agheyisi E. J. (2012), Channels And Institutions Of Informal Land Delivery In The Urbanizing Fringes Of Benin City. Sokoto Journal of the Social Sciences Vol. 2 No.1

v. Aribigbola A (2008). "Housing Policy Formulation in Developing Countries: Evidence of Programme Implementation from Akure, Ondo State. Nig. J. Human Ecol., 23(2): 125-134.

vi. Danladi, A. A. (2016). Appraisal of Informal Access to land for Housing delivery in Karu area of Nasarawa State. Minna, Nigeria: Unpublished M.Tech. URP Thesis, Federal University of Science and Technology.

vii. Hanstad, T., Nielsen, R., \& Brown, J. (2004). Land and Livelihoods: Making Land Rights Real for India's Rural Poor. Land and Livelihoods, LSP Working Paper 12. FAO.

viii. Ikejiofor, C., Nwogu, K. C., \& Nwanunobi, C. O. (2004). Informal Land Delivery Processes and access to Land for the Poor in Enugu. Informal Land Delivery in African Cities Working Report 2. Birmingham: International Development Department, School of Public Policy, University of Birmingham.

ix. Isma'il, M., Ishaku, E., Yahaya, A. M., Tanko, M. A., \& Ahmed, H. T. (2015). Urban Growth and Housing Problems in Karu Local Government Area of Nasarawa State, Nigeria. Global Journal of Research and Review, 2(1), 45-57.

x. Kironde, J. M. (1995). Access to land by the urban poor in Tanzania: some findings from Dares Salaam. Environment and Urbanization, 7(1), 77-96.

xi. Lamond, J., Awuah, B. K., Lewis, E., Bloch, R., \& Falade, B. J. (2015). Urban Land, Planning and Governance Systems in Nigeria. London: ICF International.

xii. Makinde, O. O. (2014). Housing delivery system, need and demand. Environment, Development and Sustainability, $16,49-69$.

xiii. Nkurunziza, E. (2008). Understanding Informal Urban Land Access Processes from a Legal Pluralist Perspective: The Case of Kampala, Uganda. Habitat International, 32(1), 109-120.

xiv. Oduwaye, A. O. (1998). Beyond structural adjustment programme: Strategic options for increasing housing.

xv. Oloyede, S.A. etal (2011), Informal land market: Alternative approach to mass residential housing provision in South-Western Nigeria, Journal of Geography and Regional Planning Vol. 4(11), 602-603

xvi. Owoeye, O. J., \& Adedeji, Y. M. (2015). Urban Land Acquisition for Sustainable Housing Delivery in Akure, Nigeria. International Journal of Developing Societies, 4(1), 10-20.

xvii. Rakodi, C. (2005). Land for housing in African cities: are informal delivery systems institutionally robust and propoor? World Bank Urban Research Symposium, 1-12.

xviii. Rakodi, C., \& Leduka, R. C. (2003). Informal land delivery processes and access to land for the poor in six African cities: Towards a conceptual framework. Informal/ and delivery processes and access to land for the poor in African cities: Working paper I, Birmingham: University of Birmingham.

xix. Sulyman, A. O. (2015). Introduction to Housing: Basic Concept and Applications. Minna, Niger State: King James Publishing House.

xx. Thellane, M. L. (2008). Making Land Available for Affordable Housing:Challenges for Local Government. Master Thesis. Johannesburg: University of the Witwatersrand.

xxi. ThirkellA. J. (1996) Players in urban informal land markets: A case study of Cebu City, International Journal of Environment and Urbanization, Vol. 8(2), 71-90

xxii. UN-Habitat. (2010). Urban Land Markets: Economic Concepts and Tools for Engaging in Africa. Kenya: UN-Habitat.

xxiii. Wadhwa, K. (1988). Housing Programmes for Urban Poor: Shifting Priorities. Economic and Political Weekly, 23(34), 1762-1767. 